Universal Decimal Classification (UDC) 614.7: 616.24

\title{
INDIVIDUAL RISK ASSESSMENT OF METABOLIC DISORDERS IN CHILDREN AT EXPOSURE TO CHLOROFORM IN DRINKING WATER
}

\author{
K.P. Luzhetskiy ${ }^{1,2}$, P.Z. Shur ${ }^{1,2}$, O.Yu. Ustinova ${ }^{1,2}$, O.V. Dolgikh ${ }^{1,2}$, D.A. Kiryanov ${ }^{1,2}$, V.M. \\ Chigvintsev ${ }^{1}$ \\ ${ }^{1}$ FBSI "Federal Scientific Center for Medical and Preventive Health Risk Management Technologies", Russian \\ Federation, Perm, 82 Monastyrskaya ul., 614045 \\ ${ }^{2}$ FSBEI “Perm State National Research University”, Russian Federation, Perm, 15 Bukireva ul., 614990
}

\begin{abstract}
The article provides an individual risk assessment of metabolic disorders in the child population, consuming drinking water with elevated levels of chloroform. Contingents of children threatened by the development of metabolic disorders are revealed, with a variation of the serotonin receptor gene $A G$ (HTR2A), with increased susceptibility to oral exposure to environmental organochlorines. It was found that children with the gene variation AG HTR2A have the content of serotonin functionally associated with this gene variation reduced by 1.3 times in the blood serum, relative to the comparison group. Individual risk of adverse effects (metabolic abnormalities: excess food and obesity E66.0 E67.8) in these persons is higher

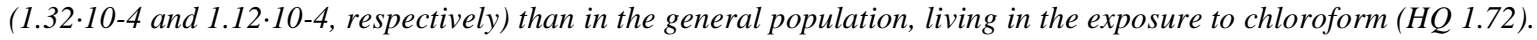

Key words: individual risk, metabolic polymorphisms of candidate genes, excess body weight, obesity, chloroform.
\end{abstract}

The right of RF citizens to favorable environment, safe water, and satisfaction of physiological and utility water demand is reserved in the Russian Constitution and the RF law. The State Report "on the sanitary and epidemiological wellbeing in the Russian Federation in 2014" indicates that only $63.9 \%$ of the population is provided with safe drinking water; $15.5 \%$ of samples do not meet the hygienic and sanitary requirements. For this reason, chlorine treatment of drinking water in the centralized utility and drinking water system is one of the most effective decontamination methods [11].

Trihalomethanes, such as chloroform $[2,4,7$, $11,17]$, is a chemical factor that contaminates drinking water and thus constitutes a major health hazard that can cause metabolic disorders (diseases of fat and carbohydrate metabolism) with chronic peroral intake $[2,4,7,11,17]$. In a human body, chlorine and its compounds administered from the environment form metabolites which are more toxic than the original pollutants, which can overcome the blood-brain and placental barriers, cumulate in the adipose tissue, by alkylation, and (or) stimulation of lipid peroxidation damage the plasma and intracellular membranes, and triggering calcium mechanisms of cell death and disruption of lipid metabolism [1].

Elevated levels of organochlorine compounds (OCC) in the drinking water can be hazardous to public health: they can increase general and child morbidity, cause disorders of the regulatory systems and major metabolic activities [3, 6 7]. Metabolic disorders (excess body weight and obesity) are developing, first and foremost, in the setting of an unbalanced diet; they are multifactorial and have genetic predisposition; the modulating role of environmental factors, is

C) Luzhetskiy K.P., Shur P.Z., Ustinova O.Yu., Dolgikh O.V., Kiryanov D.A., Chigvintsev V.M., 2015

Luzhetskiy Konstantin Petrovich - Candidate of Medicine, Head of the clinic of eco-dependent and industry-induced pathology (e-mail: nemo@ fcrisk.ru; tel.: +7 (342) 236-80-98). 33-37).

Shur Pavel Zalmanovich - Doctor of Medicine, Professor, academic secretary (e-mail: shur@ fcrisk.ru; tel.: +7 (342) 238-

Ustinova Olga Yurievna - Doctor of Medicine, Professor, FBSI Deputy Director for medical work (e-mail: ustinova@fcrisk.ru; tel.: +7 (342) 236-32-64).

Dolgikh Oleg Vladimirovich - Doctor of Medicine, Professor, Head of the Department of immunobiological diagnostic methods, Professor of the Department of Environmental Protection, Professor of the Department of Human Ecology and Life Safety (e-mail: oleg@ fcrisk.ru; tel.: +7 (342) 236-39-30).

Kiryanov Dmitry Aleksandrovich - Candidate of Technical Sciences, head of the department of mathematical modeling of systems and processes (e-mail: kda@ fcrisk.ru; tel.: +7 (342) 237-18-04).

Chigvintsev Vladimir Mikhailovich - Researcher at the Department of mathematical modeling of systems and processes (e-mail: cvm@ fcrisk.ru; tel.: +7 (342) 237-18-04). 
gaining greater importance $[12,13]$.

The probability of negative effects associated with technogenic environmental factors, as reported in various scientific sources, can be explained by individual sensitivity $[8,18]$. Regulatory and methodological documents define individual health risk as a possibility of negative health effects resulting from environmental exposure over a certain period of time and affecting some representatives in a group; this approach does not account for personal constitutional characteristics of some individuals. $[5,15,16]$.

In the present study, we define individual risk' as a possibility of development of negative health effects with the account for biological (including biological, for example genetic characteristics of an individual,

For this reason, quantitative assessment of the health risk associated with the hazardous factors, with the account for individual characteristics of the biological status of a human body, is becoming of considerable importance.

The purpose of the study is to conduct an assessment of an individual risk of metabolic disorders in children exposed to chloroform in drinking water.

Materials and methods. A hygienic assessment of the quality of drinking water and the level of chloroform was conducted in Perm Krai. The population here regularly consumes water with elevated OCC levels from the centralized utility and drinking water system. Drinking water in Perm comes from the surface water intake where the water is treated with disinfectants (liquid chlorine or sodium hypochlorite). The assessment of the observed OCC levels in drinking water was conducted on the basis of a comparative analysis with the maximum allowable concentrations in the water of water bodies, as regulated by the GN 2.1.5.1315-03 "Maximum allowable concentrations (MAC) of chemicals in the utility and drinking water system". In the course of the study, we also used the observed data for 20132014 (provided by the Center of Hygiene and Epidemiology in Perm Krai) and findings (provided by the Federal Scientific Center for Medical and Preventive Health Risk Management Technologies).

The observation group included 212 children (114 boys and 98 girls) aged 4-10 (6,33 $\pm 1,63$ years) who for an extended period of time had been consuming drinking water of poor quality in terms of the chloroform content - up to 2.8 MAC $(0,15-0,17 \mathrm{mg} / \mathrm{l}$, for nonstandard samples - 78$100 \%$ ). The control group 146 children (78 boys and 68 girls, $p \geq 0,05)$ of the similar age $(6,07 \pm 1,74$ years, $p \geq 0,05$ ), who had been consuming drinking water that met the hygienic standards (chloroform content $-0.0003-0,0004 \mathrm{mg} / \mathrm{l})$. We did not reveal other drinking water contaminants that exceeded MAC and could affect the endocrine system and hormonogenesis. The study groups were comparable in age, gender, ethnic composition, comorbidity, socio-economic level of the family, and the quality of the diet.

The blood chloroform level for each test was regarded as a marker of exposure [4, 6, 22]. Determination of the blood chloroform levels in children was carried out using the gas chromatograph "Crystall-5000" with a capillary column DB-624 and selective electron capture detector in accordance with the MUK 4.1.2115-06.

The indicators that characterized the variations of 9 pathogenetically important for the development of metabolic disorders (including antioxidants) genes (glutathione transferase (GSTA4), sulfotransferase (Sulta), superoxide dismutase 2 (SOD2), estrogen receptor (ESR1), serotonin receptor (HTR2A), protein sirtuin (SIRT1), gamma receptor peroxisome (PPARG), protein apo-E (APOE) and progesterone receptor (NR3C1), were identified as individual susceptibility markers (markers of susceptibility to negative response to chloroform). To study the polymorphic variants in the studied genes, we used the PCR technique based on the amplification reaction and detection of PCR products. The selection of material was carried out by taking a swab from the mucosa of the oropharynx. DNA extraction was then performed using a sorbent method. To determine the genotype of the patient, we used the method of allelic discrimination [10].

Modelling of the effect of chloroform on the development of disorders in the lipid and carbohydrate metabolism, for all subpopulations, and for the most sensitive subgroups was performed in accordance with MR 2.1.10.0062-12 [9], by constructing logistic regression models for various exposure levels. The likelihood of developing various disorders in the lipid and carbohydrate metabolism, depending on the level of exposure (concentration of chloroform in the blood) in children with gene variations, was described logistic function: 


$$
p=\frac{1}{1+e^{-\left(b_{0}+b_{1} x\right)}} .
$$

Health risk assessment $(R)$ was conducted with the account for the possibility $(p)$ and severity $(g)$ of disorder using the following formula: $R=p \cdot g$. The indicator of the severity of disorders in the lipid and carbohydrate metabolism (ICD: E67.8 - body mass excess, E66.0 - obesity) was evaluated in accordance with the health disorder severity scale, at the upper end, for mild disorders - 0,0004 [14].

Comparison of the groups by the quantitative indicators was conducted with the help of twosample Student-t. The importance of the relationship and differences between the samples were considered significant at a value for $\mathrm{p}<0.05$. Correlation analysis was conducted using the Spearman's method. The tests for compliance with Hardy-Weinberg equilibrium and identification of associations using Pearson's $\chi 2$ were done using GenExpert software (The RF State Research Center "State Scientific and Research Institute Genetika). The groups under study were in an equilibrium (steady) state by the genotype frequencies of studied genes $(\mathrm{p}<0.05)$. The obtained information was analyzed using Statistica 7.0 and the software products associated with MS Office.

Results and discussion. Based on the medical referrals in 2013, the prevalence of endocrine pathology in children residing in the area of study constituted $175,0 \%$, which is 2.3 times higher than in the comparison area $-74,9 \%$. Various forms of the lipid and carbohydrate metabolism disorders (excessive nutrition - 17,4\%o, obesity $-30,6 \%$ ) were diagnosed as the priority endocrine pathology; their prevalence in the previous three years 4.2-7.0 and 6.4-8.5 times increased the levels in the comparison area $(2.4-4.1 \% o$ and $3.6-9.4 \%$ respectively, $p=0,001$ $0,041)$.

According to the chemical-analytical blood tests, a range of individual chloroform concentrations ranged from 0.01 to $6.0 \mu \mathrm{g} / \mathrm{l}$ (the average for the group - $0,69 \pm 0,04 \mu \mathrm{g} / \mathrm{l}$, the reference concentration $0,0 \pm 0,0 \mu \mathrm{g} / \mathrm{l}, \rho<0,01)$, which is 2.3 times higher than in control group $(0,29 \pm 0,01 \mu \mathrm{g} / \mathrm{l})(\rho<0,05)$.

Table 1

The prevalence of polymorphisms of genes in the groups of children under study

\begin{tabular}{|c|c|c|c|c|c|c|}
\hline \multirow[b]{2}{*}{ Gene } & \multirow[b]{2}{*}{ Genotype/allele } & \multicolumn{2}{|c|}{ Observation group $(n=24)$} & \multicolumn{2}{|c|}{ Comparison group $(n=24)$} & \multirow[b]{2}{*}{$\mathrm{p}$} \\
\hline & & $\begin{array}{c}\text { Prevalence, abs.. (rel. \%, } \\
(\mathrm{M} \pm \mathrm{m})\end{array}$ & frequency & $\begin{array}{l}\text { Prevalence, abs.. (rel. \%, } \\
\text { M } \pm \text { m) }\end{array}$ & frequency & \\
\hline \multirow{5}{*}{ APOE } & $\mathrm{T}$ & $30(62,5 \pm 6,9)$ & 0,62 & $34(70,8 \pm 6,5)$ & 0,71 & \multirow{2}{*}{0,51} \\
\hline & $\mathrm{C}$ & $18(37,5 \pm 6,9)$ & 0,37 & $14(29,2 \pm 6,5)$ & 0,29 & \\
\hline & TT & $6(25,0 \pm 8,4)$ & 0,25 & $10(41,7 \pm 10,7)$ & 0,42 & 0,22 \\
\hline & TC & $18(75,0 \pm 8,4)$ & 0,75 & $14(58,3 \pm 10,7)$ & 0,58 & 0,22 \\
\hline & $\mathrm{CC}$ & $0(0,0 \pm 0,0)$ & 0,00 & $0(0,0 \pm 0,0)$ & 0,00 & 1,0 \\
\hline \multirow{5}{*}{ HTR2A } & $\mathrm{A}$ & $14(31,8 \pm 6,7)$ & 0,32 & $24(54,7 \pm 7,2)$ & 0,55 & \multirow{2}{*}{0,11} \\
\hline & $\mathrm{G}$ & $30(68,2 \pm 6,7)$ & 0,68 & $20(45,5 \pm 7,2)$ & 0,45 & \\
\hline & AA & $2(9,1 \pm 5,8)$ & 0,09 & $10(45,5 \pm 10,6)$ & 0,45 & 0,005 \\
\hline & $\mathrm{AG}$ & $10(45,5 \pm 10,2)$ & 0,45 & $4(18,2 \pm 7,9)$ & 0,18 & 0,04 \\
\hline & GG & $10(45,5 \pm 10,2)$ & 0,45 & $8(36,4 \pm 9,8)$ & 0,36 & 0,52 \\
\hline \multirow{5}{*}{ SOD2 } & $\mathrm{C}$ & $16(36,4 \pm 6,9)$ & 0,36 & $34(77,3 \pm 6,1)$ & 0,77 & \multirow{2}{*}{0,004} \\
\hline & $\mathrm{A}$ & $28(63,6 \pm 6,9)$ & 0,63 & $10(22,7 \pm 6,1)$ & 0,23 & \\
\hline & $\mathrm{CC}$ & $2(9,1 \pm 5,9)$ & 0,09 & $12(54,5 \pm 10,2)$ & 0,54 & 0,001 \\
\hline & $\mathrm{CA}$ & $12(54,5 \pm 10,2)$ & 0,54 & $10(45,5 \pm 10,2)$ & 0,45 & 0,53 \\
\hline & AA & $8(36,4 \pm 9,8)$ & 0,36 & $0(0,0 \pm 0,0)$ & 0,00 & 0,001 \\
\hline \multirow{5}{*}{ PPARGC1A } & $\mathrm{G}$ & $26(54,2 \pm 7,2)$ & 0,54 & $34(70,8 \pm 6,5)$ & 0,71 & \multirow{2}{*}{0,22} \\
\hline & $\mathrm{A}$ & $22(45,8 \pm 7,2)$ & 0,46 & $14(29,9 \pm 6,5)$ & 0,3 & \\
\hline & GG & $10(41,7 \pm 10,1)$ & 0,42 & $12(50,0 \pm 10,2)$ & 0,5 & 0,58 \\
\hline & GA & $6(25,0 \pm 8,8)$ & 0,25 & $10(41,7 \pm 10,1)$ & 0,42 & 0,22 \\
\hline & AA & $8(33,3 \pm 9,6)$ & 0,33 & $2(8,3 \pm 5,5)$ & 0,08 & 0,03 \\
\hline \multirow{5}{*}{ SULTA } & $\mathrm{G}$ & $28(58,3 \pm 7,1)$ & 0,58 & $32(66,7 \pm 6,8)$ & 0,67 & \multirow{2}{*}{0,52} \\
\hline & $\mathrm{A}$ & $20(41,7 \pm 7,1)$ & 0,42 & $16(33,3 \pm 6,8)$ & 0,33 & \\
\hline & GG & $6(25,0 \pm 8,8)$ & 0,25 & $12(50,0 \pm 10,2)$ & 0,50 & 0,074 \\
\hline & GA & $16(66,7 \pm 9,6)$ & 0,67 & $8(33,3 \pm 9,6)$ & 0,33 & 0,019 \\
\hline & $\overline{\mathrm{AA}}$ & $2(8,3 \pm 5,5)$ & 0,08 & $4(16,7 \pm 7,7)$ & 0,17 & 0,35 \\
\hline
\end{tabular}

Note: $\mathrm{p}$ - significant differences in the study groups $\leq 0,05$. 
Table 2

The assessment of individual risk of metabolic disorders in children with HTR2A gene variations at different levels of the blood content of chloroform (the permissible level of risk - less than $1 \cdot 10^{-4}$ )

\begin{tabular}{|c|c|c|c|c|c|}
\hline \multirow{2}{*}{$\begin{array}{l}\text { Blood level of } \\
\text { chloroform, } \mu \mathrm{g} \\
/ 1\end{array}$} & \multirow{2}{*}{$\begin{array}{l}\text { Exclusiv } \\
\text { e of } \\
\text { genotype }\end{array}$} & \multicolumn{2}{|c|}{ E67.8 } & \multicolumn{2}{|c|}{ E66.0 } \\
\hline & & $\begin{array}{l}\text { HTR2A gen normal } \\
\text { homozygous AA }\end{array}$ & $\begin{array}{l}\text { HTR2A gene mutant } \\
\text { heterozygous AG }\end{array}$ & $\begin{array}{l}\text { HTR2A gene normal } \\
\text { homozygous AA }\end{array}$ & $\begin{array}{l}\text { HTR2A gene mutant } \\
\text { heterozygous AG }\end{array}$ \\
\hline 0,01 & $2,26 \cdot 10^{-5}$ & $1,07 \cdot 10^{-5}$ & $1,29 \cdot 10^{-5}$ & $5,95 \cdot 10^{-6}$ & $6,66 \cdot 10^{-6}$ \\
\hline 0,21 & $2,38 \cdot 10^{-5}$ & $1,16 \cdot 10^{-5}$ & $1,41 \cdot 10^{-5}$ & $6,00 \cdot 10^{-6}$ & $7,41 \cdot 10^{-6}$ \\
\hline 0,41 & $2,51 \cdot 10^{-5}$ & $1,24 \cdot 10^{-5}$ & $1,54 \cdot 10^{-5}$ & $6,05 \cdot 10^{-6}$ & $8,24 \cdot 10^{-6}$ \\
\hline 0,83 & $2,79 \cdot 10^{-5}$ & $1,44 \cdot 10^{-5}$ & $1,84 \cdot 10^{-5}$ & $6,16 \cdot 10^{-6}$ & $1,02 \cdot 10^{-5}$ \\
\hline 1,03 & $2,95 \cdot 10^{-5}$ & $1,55 \cdot 10^{-5}$ & $2,01 \cdot 10^{-5}$ & $6,21 \cdot 10^{-6}$ & $1,13 \cdot 10^{-5}$ \\
\hline 1,24 & $3,11 \cdot 10^{-5}$ & $1,67 \cdot 10^{-5}$ & $2,19 \cdot 10^{-5}$ & $6,27 \cdot 10^{-6}$ & $1,26 \cdot 10^{-5}$ \\
\hline 1,45 & $3,27 \cdot 10^{-5}$ & $1,79 \cdot 10^{-5}$ & $2,39 \cdot 10^{-5}$ & $6,32 \cdot 10^{-6}$ & $1,39 \cdot 10^{-5}$ \\
\hline 1,86 & $3,63 \cdot 10^{-5}$ & $2,07 \cdot 10^{-5}$ & $2,85 \cdot 10^{-5}$ & $6,43 \cdot 10^{-6}$ & $1,72 \cdot 10^{-5}$ \\
\hline 2,07 & $3,82 \cdot 10^{-5}$ & $2,22 \cdot 10^{-5}$ & $3,10 \cdot 10^{-5}$ & $6,49 \cdot 10^{-6}$ & $1,90 \cdot 10^{-5}$ \\
\hline 2,28 & $4,02 \cdot 10^{-5}$ & $2,39 \cdot 10^{-5}$ & $3,38 \cdot 10^{-5}$ & $6,55 \cdot 10^{-6}$ & $2,11 \cdot 10^{-5}$ \\
\hline 2,48 & $4,24 \cdot 10^{-5}$ & $2,57 \cdot 10^{-5}$ & $3,68 \cdot 10^{-5}$ & $6,60 \cdot 10^{-6}$ & $2,34 \cdot 10^{-5}$ \\
\hline 2,90 & $4,69 \cdot 10^{-5}$ & $2,95 \cdot 10^{-5}$ & $4,34 \cdot 10^{-5}$ & $6,72 \cdot 10^{-6}$ & $2,86 \cdot 10^{-5}$ \\
\hline 3,10 & $4,93 \cdot 10^{-5}$ & $3,17 \cdot 10^{-5}$ & $4,72 \cdot 10^{-5}$ & $6,78 \cdot 10^{-6}$ & $3,16 \cdot 10^{-5}$ \\
\hline 3,31 & $5,18 \cdot 10^{-5}$ & $3,40 \cdot 10^{-5}$ & $5,12 \cdot 10^{-5}$ & $6,84 \cdot 10^{-6}$ & $3,49 \cdot 10^{-5}$ \\
\hline 3,52 & $5,44 \cdot 10^{-5}$ & $3,64 \cdot 10^{-5}$ & $5,55 \cdot 10^{-5}$ & $6,90 \cdot 10^{-6}$ & $3,85 \cdot 10^{-5}$ \\
\hline 3,93 & $6,00 \cdot 10^{-5}$ & $4,18 \cdot 10^{-5}$ & $6,49 \cdot 10^{-5}$ & $7,02 \cdot 10^{-6}$ & $4,67 \cdot 10^{-5}$ \\
\hline 4,14 & $6,29 \cdot 10^{-5}$ & $4,47 \cdot 10^{-5}$ & $7,01 \cdot 10^{-5}$ & $7,08 \cdot 10^{-6}$ & $5,14 \cdot 10^{-5}$ \\
\hline 4,34 & $6,60 \cdot 10^{-5}$ & $4,78 \cdot 10^{-5}$ & $7,57 \cdot 10^{-5}$ & $7,14 \cdot 10^{-6}$ & $5,64 \cdot 10^{-5}$ \\
\hline 4,55 & $6,92 \cdot 10^{-5}$ & $5,11 \cdot 10^{-5}$ & $8,15 \cdot 10^{-5}$ & $7,20 \cdot 10^{-6}$ & $6,19 \cdot 10^{-5}$ \\
\hline 4,97 & $7,59 \cdot 10^{-5}$ & $5,82 \cdot 10^{-5}$ & $9,42 \cdot 10^{-5}$ & $7,33 \cdot 10^{-6}$ & $7,40 \cdot 10^{-5}$ \\
\hline 5,17 & $7,95 \cdot 10^{-5}$ & $6,21 \cdot 10^{-5}$ & $1,01 \cdot 10^{-4}$ & $7,39 \cdot 10^{-6}$ & $8,08 \cdot 10^{-5}$ \\
\hline 5,38 & $8,32 \cdot 10^{-5}$ & $6,62 \cdot 10^{-5}$ & $1,08 \cdot 10^{-4}$ & $7,46 \cdot 10^{-6}$ & $8,80 \cdot 10^{-5}$ \\
\hline 5,59 & $8,70 \cdot 10^{-5}$ & $7,05 \cdot 10^{-5}$ & $1,16 \cdot 10^{-4}$ & $7,52 \cdot 10^{-6}$ & $9,56 \cdot 10^{-5}$ \\
\hline 5,79 & $9,09 \cdot 10^{-5}$ & $7,50 \cdot 10^{-5}$ & $1,23 \cdot 10^{-4}$ & $7,59 \cdot 10^{-6}$ & $1,04 \cdot 10^{-4}$ \\
\hline 6,00 & $9,50 \cdot 10^{-5}$ & $7,97 \cdot 10^{-5}$ & $1,32 \cdot 10^{-4}$ & $7,65 \cdot 10^{-6}$ & $1,12 \cdot 10^{-4}$ \\
\hline
\end{tabular}

During the health risk study it was determined that ingestion of chloroform with drinking water causes unacceptable non-carcinogenic risk of the endocrine system disease $(\mathrm{HQ}=1.72)$ in the exposed children

An in-depth clinical medical study showed that endocrine disorders ranked third in the overall morbidity in the observation group; they were diagnosed twice as frequently $(23.8 \%)$ as in the comparison group $(10.7 \%)$; the odds ratio here totaled $-\mathrm{OR}=2.39 ; \mathrm{CI} 0.84-6.82 ; \mathrm{r} \geq 0.05$. The following main nosological forms prevailed in the overall morbidity in children from the observation group: excess nutrition (E67.8) - 10.7\% and obesity (E66.0) $-5.3 \%$, which is 2.4 times more than in the comparison group (4.3\% and $2.2 \%$, respectively).

According to a genetic testing of children with a long-term HOS exposure and consuming drinking water with elevated levels of chloroform, polymorphism of the candidate genes HTR2A and SOD2 was characterized by increased incidence of the mutant homozygous and heterozygous genotype by $1.7-2.0$ times relative to the group comparisons $(\mathrm{p}=0.001-0.005)($ Table 1$)$.
Modeling did not reveal significant differences in the variations of the gene superoxide dismutase2 (SOD2) from the figures for the total sample. Therefore, variations of this gene should not be viewed as markers of sensitivity to changes in the endocrine system under chloroform exposure. As a marker of individual sensitivity to the chloroform exposure for the development of metabolic disorders later analyzed the variation of the serotonin receptor gene (HTR2A) [19, 21].

As a marker of individual susceptibility to chloroform exposure for the development of metabolic disorders, we further analyzed the variation of the serotonin receptor gene (HTR2A) $[19,21]$.

According to the genetic testing, the prevalence of AA variation of gene HTR2A in the test sample reaches $50.5 \%$, AG variation $-33.3 \%$ GG variation $-16.2 \%$.

When assessing individual risk for the sample at large, we identified the coefficients that describe the relationship between the possibility of metabolic disorders and excessive nutrition $\left(b_{0}=-\right.$ 2.13, $b_{1}=238.4$ ), and obesity and chloroform 
exposure $\left(b_{0}=-3.25, b_{1}=294.6\right)$. Parameters of the models for this relationship that describe individual sensitivity included: in case of excessive nutrition for the children with AG variation of gene HTR2A $\mathrm{b} 0=-3.68, \mathrm{~b} 1=364,7$, with AA variation - $\mathrm{b} 0=-$ 3,68 ; b1 $=336,1$; in case of obesity for the children with $A G$ variation - $b 0=-4,42$; b1 $=486,1$, with AA variation - $b 0=-4,65$; $b 1=17,68$.

The health risk assessment results shown in Table 2 indicate differences in the individual sensitivity to chloroform exposure in the children with the gene variation HTR2A that determines the transmission of a signal to the serotonin receptor and is pathogenetically connected to the development of lipid and carbohydrate metabolism disorders. Conspicuous is the fact that if you study a subpopulation at large, the level of health risk manifested by the development of metabolic disorders is estimated to be acceptable in the whole range of values of the exposure marker in children with the AG variation of gene HTR2A, an unacceptable level of risk of the development of excessive nutrition is registered starting from the blood level of chloroform at $5.17 \mu \mathrm{g} / \mathrm{l}$, obesity with a level of $5.79 \mu \mathrm{g} / \mathrm{l}$.

The assessment of individual risks of metabolic disorders in children and the model parameters are verified by the results of enzymeimmunoassay of the serotonin level in the blood serum functionally related to the indicated variations of $H T R 2 A$ gene responsible for the dietary motivation and coding the serotonin receptors. In children with heterozygous variations of this gene, in the setting of peroral exposure to chloroform, there is a tendency to a 1.3 time decrease in blood serum serotonin $(216.0 \pm 105.8$ $\mathrm{ng} / \mathrm{ml}$ ), as compared to the comparison group $(282.8 \pm 136.3 \mathrm{ng} / \mathrm{ml})$.
The detected deviations in the disturbance of serotonin synthesis via the central regulatory mechanisms may promote the changes in the normal structure of the dietary behavior, and potentiate disorders of the lipid and carbohydrate metabolism [20].

Conclusion. The exposed children are facing a growing unacceptable non-carcinogenic risk of endocrine pathology associated with oral exposure to chloroform in drinking water (HQ 1.72). An individual health risk assessment with the exposure marker (concentration of chloroform in the blood) in the range from 0.01 to $6.0 \mu \mathrm{g} / \mathrm{l}$ showed that the total risk in the sample at large is characterized as acceptable (less than $1.0 * 10-4$ ). At the same time, for individuals with AG variation of HTR2A gene, with the blood level of chloroform higher than 5.17 $\mu \mathrm{g} / \mathrm{l}$ and $5.79 \mu \mathrm{g} / \mathrm{l}$, individual risk of metabolic disorders - excessive nutrition and obesity (ICD: E67. 7-66.0) can reach impermissible values (1.32 $\times 10^{-4}$ and $1.12 \times 10^{-4}$, respectively).

The children with AG variation of HTR2A gene shall be viewed as most chloroform sensitive contingents, and this gene variation shall be considered a marker of individual sensitivity. To a relative deficiency of serotonin, in addition to an unbalanced diet, may also result in the consumption of drinking water with a high content of organochlorine compounds.

The conducted studies can validate the genetic indicators of sensitivity to chloroform for the purposes of early pre-nosological diagnostics of metabolic disorders and prevent excessive nutrition and obesity (MKB: E67.7-66.0) in the children consuming drinking water with elevated levels of organochlorines.

\section{References}

1. Rakov A.L., Sesjukin A.E. Vnutrennie bolezni. Voenno-polevaja terapija: uchebnoe posobie [Internal diseases. Military Field Therapy: Textbook]. St. Petersburg: Izd-vo FOLIANT, 2003, 384 p. (in Russian).

2. Voinceva I.I. Poligeksametilenguanidin gidrohlorid dlja ochistki i obezzarazhivanija vody kak al'ternativa reagentam-okisliteljam [Polyhexamethyleneguanidine hydrochloride for water cleaning and disinfection as an alternative to oxidizing reagents]. Voda: himija i jekologija, 2011, no. 7, pt. 1, pp. 39-45. (in Russian).

3. Iksanova T.I., Malysheva A.G., Rastjannikov E.G., Egorova N.A., Krasovskij G.N., Nikolaev M.G. Gigienicheskaja ocenka kompleksnogo dejstvija hloroforma pit'evoj vody [Hygienic evaluation of complex action of drinking water chloroform]. Gigiena i sanitarija, 2006, no. 2, pp. 8-12. (in Russian).

4. Kamilov F.K. Patohimija toksicheskogo dejstvija hlororganicheskih i aromaticheskih soedinenij [Pathochemistry of organochlorine and aromatic compounds']. Medicinskij vestnik Bashkortostana, 2007, vol. 2, no. 6, pp. 76-80. (in Russian).

5. Kompleksnoe obespechenie bezopasnosti i antiterroristicheskoj zashhishhennosti zdanij i sooruzhenij: terminologicheskij slovar' / NP SRO «Objedinenie organizacij-razrabotchikov sistem kompleksnoj bezopasnosti» [Comprehensive provision of security and counter-terrorism security of buildings and structures: Glossary / Non- 
commercial partnership Self-regulatory organization "Association of organizations- integrated security system developers"], 2010 (in Russian).

6. Krasovskij G.N., Egorova N.A. Hlorirovanie vody kak faktor povyshennoj opasnosti dlja zdorov'ja naselenija [ Water chlorination as a factor of increased danger to public health]. Gigiena i sanitarija, 2003, no. 1, pp. 17-21. (in Russian).

7. Kuzubova L. I., Kobrina V. N. Himicheskie metody podgotovki vody (hlorirovanie, ozonirovanie, ftorirovanie): Analit. obzor / SO RAN, GNNTB, NIOH [Chemical methods of water treatment (chlorination, ozonation, fluoridation): Analyt. review / SB RAS, SPSL, NIOC]. Novosibirsk, 1996, 132 p. (in Russian).

8. Luzhnikov E. A. Klinicheskaja toksikologija. - 2-e izd. pererab. i dopolnen. [Clinical Toxicology. - 2nd ed. Revised and enlarged]. Moscow: Medicina, 1994, 256 p. (in Russian).

9. Kolichestvennaja ocenka nekancerogennogo riska pri vozdejstvii himicheskih veshhestv na osnove postroenija jevoljucionnyh modelej: Metodicheskie rekomendacii MR 2.1.10.0062-12 [Quantitative assessment of carcinogenic risk when exposed to chemicals on the basis of construction of evolutionary patterns: Guidelines MR 2.1.10.0062-12]. Federal'naja sluzhba po nadzoru v sfere zashhity prav potrebitelej i blagopoluchija cheloveka, Moscow: Federal'nyj centr gigieny i jepidemiologii Rospotrebnadzora, 2012, 36 p. (in Russian).

10. Perechen' markerov gennogo polimorfizma, otvechajushhih za osobennosti mutagennoj aktivnosti tehnogennyh himicheskih faktorov / Metodicheskie rekomendacii MR 4.2.0075-13 [List of gene polymorphism markers responsible for man-made features of chemical factors' mutagenic activity Guidelines MR 4.2.0075-13]. Moscow: Federal'nyj centr gigieny i jepidemiologii Rospotrebnadzora, 2013, 24 p. (in Russian).

11. Mazaev V.T., Il'nickij A.P., Shlepina T.G. Rukovodstvo po gigiene pit'evoj vody i pit'evogo vodosnabzhenija [Guidelines for drinking water hygiene and drinking water supply]. Moscow: Medicinskoe informacionnoe agentstvo, 2008, 320 p. (in Russian).

12. Ozhirenie i izbytochnyj ves: Informacionnyj bjulleten' VOZ № 311. Janvar' 2015 g. [Obesity and overweight: WHO Fact Sheet № 311, January 2015]. Available at: http: //www.who.int/mediacentre/factsheets/fs311/ru/ (11.10.2015) (in Russian).

13. Luzhetskiy K.P., Ustinova O.Ju., Maklakova O.A., Palagina L.N. Osobennosti jendokrinnyh narushenij $\mathrm{u}$ detej, prozhivajushhih $\mathrm{v}$ uslovijah vysokogo riska ingaljacionnogo vozdejstvija benzola, fenola i bez(a)pirena [Features of endocrine disorders in children living in high-risk exposure to inhaled benzene, phenol and benzo(a)pyrene]. Analiz riska zdorov'ju, 2014, no. 2, pp. 97-103. (in Russian).

14. Rukovodstvo po ocenke riska dlja zdorov'ja naselenija pri vozdejstvii himicheskih veshhestv, zagrjaznjajushhih okruzhajushhuju sredu R.2.1.10.1920-04 [Guidelines for assessing health risk in the population exposed to the chemicals polluting the environment R.2.1.10.1920-04]. - Moscow: Federal'nyj centr Gossanjepidnadzora Minzdrava Rossii, 2004, 143 p. (in Russian).

15. Slovar' terminov MChS [MOE Glossary], 2010 g. (in Russian).

16. Zaitseva N.V., May I.V., Shur P.Z., Trusov P.V., Shevyreva M.P., Goncharuk N.N. Pat. 2368322 Rossijskaja Federacija. Sposob opredelenija integral'nogo dopustimogo riska otdel'nyh klassov i vidov produkcii dlja zdorov'ja chelovek. Zajavitel' i patentoobladatel' GUZ «Permskij kraevoj nauchno-issledovatel'skij klinicheskij institut jekopatologii». - nomer zajavki 2008101258; data registracii 09.01.2008; opubl. 27.09.2009. [Pat. 2368322 of the Russian Federation. The method for determining the integral tolerable risk for individual classes and types of products for human health. The applicant and patentee SHI "Perm Regional Research Clinical Institute of Ecopathology". - Application number 2008101258; Registration date 09.01.2008; publ. 27-09-2009]. (in Russian).

17. Ustinova O.Ju., Luzheckij K.P., Maklakova O.A. Hronicheskij gastroduodenit u detej, potrebljajushhih pit'evuju vodu s povyshennym soderzhaniem marganca i produktov giperhlorirovanija [Chronic gastroduodenitis in children who consume drinking water with elevated levels of manganese and hyperchlorination products]. Fundamental'nye issledovanija, 2014, no. 7, pp. 795-797. (in Russian).

18. Hajcev N.V. Vozrastnye, polovye i individual'nye osobennosti otvetnyh reakcij organizma pri dejstvii gipoksii i himicheskih veshhestv, vydeljajushhihsja iz polimernyh materialov: avtoref. dis. ... dok. biolog. nauk [Age, gender and individual characteristics of the body's responses during hypoxia and chemicals released from polymeric materials: Dis. Thesis... Doc. biologist. sciences]. Moscow, 1998, 337 p. (in Russian).

19. Brown R.E., Stevens D.R., Haas H.L. The physiology of brain histamine. Prog. Neurobiol, 2001, vol. 63, pp. 637-672.

20. Kim M., Bae S., Lim K.M. Impact of High Fat Diet-induced Obesity on the Plasma Levels of Monoamine Neurotransmitters in C57BL/6 Mice. Biomol. Therapeut, 2013, vol. 21, no. 6, pp. 476-480.

21. Nguyen T., Shapiro D.A., George S.R. et al. Discovery of a Novel Member of the Histamine Receptor Family. Mol. Pharmacol, 2001, vol. 59, no. 3, pp. 427-433.

22. White's Handbook of Chlorination and Alternative Disinfectants. Fifth Ed. / ILSI: Black\&Veatch Corp, 2010, 1062 p. 